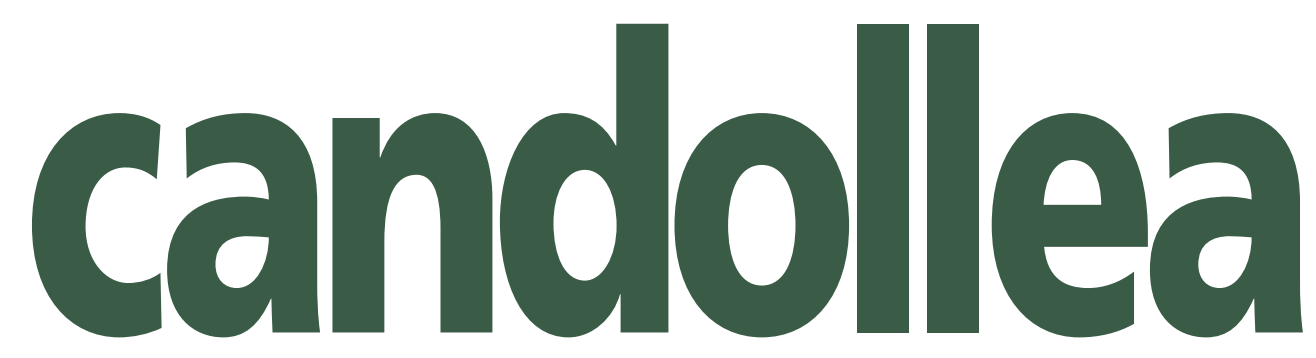

Journal international de botanique systématique

\title{
Helictochloa Romero Zarco (Poaceae), a new genus of oat grass
}

Carlos Romero-Zarco

12 juillet 2011

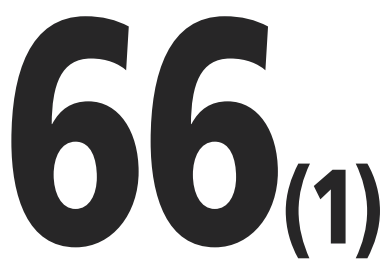





\title{
Helictochloa Romero Zarco (Poaceae), a new genus of oat grass
}

\author{
Carlos Romero-Zarco
}

\begin{abstract}
ROMERO-ZARCO, C. (2011). Helictochloa Romero Zarco (Poaceae), a new genus of oat grass. Candollea 66: 87-103. In English, English and French abstracts.

Morphological and anatomical characters used to separate the genera related to Avena L. (Poaceae: Aveneae) are analyzed. The taxonomic importance of these characters is discussed with regard to recent molecular studies. Six genera of perennial oats are recognized: Arrhenatherum P. Beauv., Pseudarrhenatherum Rouy, Helictotrichon Besser, Avenula (Dumort.) Dumort., Tricholemma (Röser) Röser and Helictochloa Romero Zarco (described here) is accepted. New combinations for the species included in Helictochloa are proposed. A key to Avena related genera from the Mediterranean region is given.
\end{abstract}

\section{Key-words}

POACEAE - Avena - Arrhenatherum - Pseudarrhenatherum - Avenula - Helictochloa - Tricholemma - HelictotrichonOat grasses - Taxonomy

\section{Résumé}

ROMERO-ZARCO, C. (2011). Helictochloa Romero Zarco (Poaceae), un nouveau genre d'avoine. Candollea 66: 87-103. En anglais, résumés anglais et français.

Les principaux caractères morphologiques et anatomiques sont présentés ici et utilisés pour servir à la délimitation des taxons les plus proches du genre Avena L. (Poaceae: Aveneae). L'importance taxonomique de ces caractères est discutée selon des études moléculaires récentes. Six genres d'avoines vivaces sont ainsi distingués: Arrhenatherum P. Beauv., Pseudarrhenatherum Rouy, Helictotrichon Besser, Avenula (Dumort.) Dumort., Tricholemma (Röser) Röser et Helictochloa Romero Zarco (décrit ici). Plusieurs nouvelles combinaisons pour les espèces incluses dans Helictochloa sont établies. Une clé de détermination est aussi donnée pour séparer les genres proches d'Avena pour la région méditerranéenne.

Address of the author: Departamento de Biología Vegetal y Ecología, apdo 1095, 41080-Sevilla, Spain.

Email: zarco@us.es 


\section{Introduction}

This article is especially focused on the so called "perennial oats" (GervaIs, 1973), that is, Avenula (Dumort.) Dumort. plus Helictotrichon Besser (Poaceae: Aveneae), a group that has been circumscribed as a single genus (HOLUB, 1958; RöSER, 1989, among others) or two (HoLUB, 1962; GeRVAIS, 1973; KERGUÉLEN, 1975; ROMERO-ZARCO, 1984a, 1984b) or four genera (RÖSER $\&$ al., 2009). Nevertheless, it is also necessary to discuss their phylogenetic relationships with Avena L., Arrhenatherum P. Beauv. and Pseudarrhenatherum Rouy at the light of recent molecular studies (RÖSER \& al., 2001; GREBENSTEIN \& al., 1995, 1998; RoDiOnOv \& al., 2005; QUINTANAR \& al., 2007; SORENG \& al., 2007; WINTERFELD \& RÖSER, 2007; SCHNEIDER \& al., 2009; WINTERFELD \& al., 2009).

"Oats grasses" is used here as the appropriate common name for species belonging to Avena, Helictotrichon, Avenula, Arrhenatherum and Pseudarrhenatherum. Other genera with nomenclatural relations with Avena or Helictotrichon, such as Amphibromus Nees, Danthoniastrum (Holub) Holub, Gaudinia P. Beauv., Ventenata Koeler, Deschampsia P. Beauv., Avenella Parl., and Trisetum Pers., etc. are not considered here, as they do not pose taxonomic problems in relation to the limits of the genus Avena. The aim of this article is to ascertain relationships among oat grasses. For this purpose anatomical and morphological characters are summarized and discussed. Consequently, a taxonomic scheme for oat grasses is here established, accepting in general the monophyletic lineages suggested by molecular studies and supported by anatomical, morphological and biogeographical evidence.

GREBENSTEIN \& al. (1995), using highly repeated satellite DNA as a molecular marker, found differences between Helictotrichon s.s. and the remaining species investigated. A second study (GREBENSTEIN \& al., 1998) concludes that Helictotrichon s.l. is paraphyletic, if not polyphyletic according to ITS1 and ITS2 rDNA sequence analysis. Further evidence from physical mapping of 5S rDNA (RöSER \& al., 2001) and from plastid 'trnT-F' and nuclear ITS sequences (QUINTANAR \& al., 2007) strongly suggest that the large genus Helictotrichon is paraphyletic or polyphyletic.

The anatomical characteristics of leaf blade in transverse section have been intensely investigated and used in the taxonomy of the group (Duval-Jouve, 1863; PotzTAL, 1951). It has been of special importance for the separation of Avenula with respect to Helictotrichon (HoLUB, 1962; Gervais, 1973; KerGuÉlen, 1975; Romero-ZARCO, 1984b). Nevertheless, molecular studies suggest that Avenula is polyphyletic (GREBENSTEIN \& al., 1998; RÖSER \& al., 2001; QUINTANAR \& al., 2007). A taxonomic consequence is the description of the monospecific genus Homalotrichon Banfi, Galasso \& Bracchi (CONTI \& al., 2005) including H. pubescens (Hudson) Banfi, Galasso \& Bracchi (三 Avenula pubescens (Hudson) Dumort. $\equiv$ Avena pubescens Hudson, see below). This implies that the conduplicated leaf blades structure, a diagnostic character for the genus, could have evolved independently in three lineages. In order to investigate this possibility, the anatomical structure of blades were re-examined in more detail in A. pubescens (placed by recent molecular analyses in an isolated position near Arctagrostis Griseb. or Milium L.; see QuINTANAR \& al., 2007), and Avenula pratensis (L.) Dumort., with strong affinity with the rest of European Avenula species, both clearly separated with respect to Helictotrichon and other Aveneae genera (GREBENSTEIN \& al., 1998; RÖSER \& al., 2001).

\section{Material and methods}

Approximately 2600 sheets (herbarium specimens) were examined for this study. Leaf blade cross-sections from sterile innovations were obtained from nearly 260 samples, following methods in SAINT-YVES (1931) and anatomical techniques described in previous papers (ROMERO-ZARCO, $1984 b, 1985 b)$. Several root samples of different diameters were removed for study from one year old plants grown in pots. For each species lodicules were observed in 10 or more florets from at least three populations when possible. Two or three dried mature caryopses samples were studied in selected species. The caryopses were softened in fresh water during six hours and then embryos were dissected using an entomological needle and placed in 50\% lactic acid. Most of the studied specimens belong to the main collection of the Servicio General de Herbarios de la Universidad de Sevilla (SEV). Vouchers cited in the figures are listed in table 1. Nomenclature used in the next section follows RoMEROZARCO (1984a, 1984b, 1985a, 1985c, 1993).

\section{Results and discussion}

\section{Root anatomy (Fig. 1)}

The presence of a ring of sclerenchyma around endodermis in several European species of Helictotrichon and in Pseudarrhenatherum longifolium (Thore) Rouy was shown by GERVAIS (1968). This periendodermic ring does not appear in Avena species, Arrhenatherum elatius (L.) J. Presl \& C. Presl, nor in Avenula species. A similar ring was described later in the roots of Pseudarrhenatherum pallens (Link) Holub by RoMERO-ZARCO (1985c). In order to complete the data, this character was investigated in Arrhenatherum album (Vahl) W. D. Clayton and, for comparison, in Pseudarrhenatherum pallens and Avenula hackelii (Henriq.) Holub. The results obtained here are in agreement with those contributed by GERVAis (1968, 1973) and by RöSER (1989). The studied species of Arrhenatherum and Avenula lack a sclerenchymatic ring, whereas this ring is present in Pseudarrhenatherum. 
Table 1. - Material cited in the figures. Nomenclature according to ROMERO-ZARCO (1984a, 1984b, 1985a, 1985c, 1993).

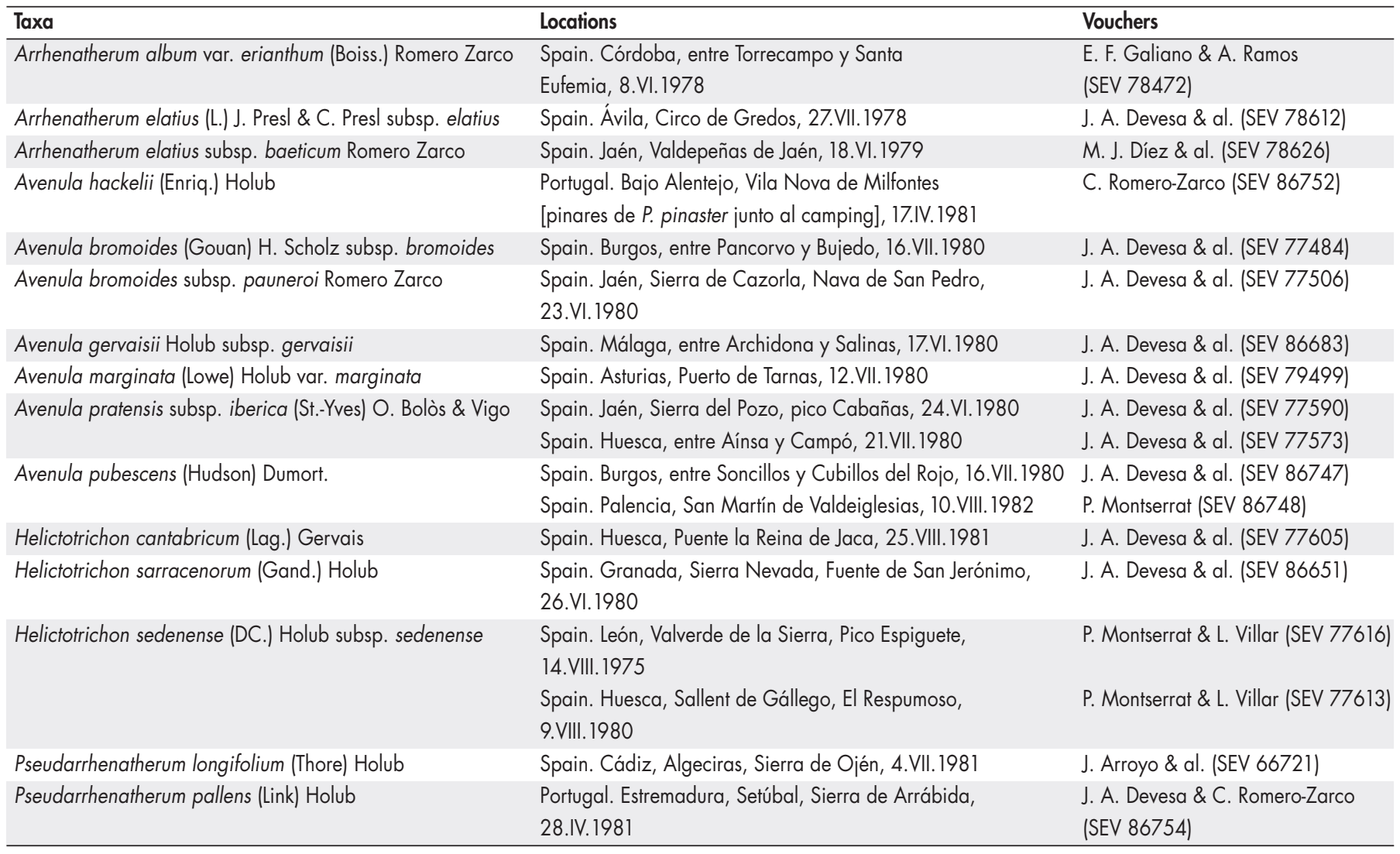

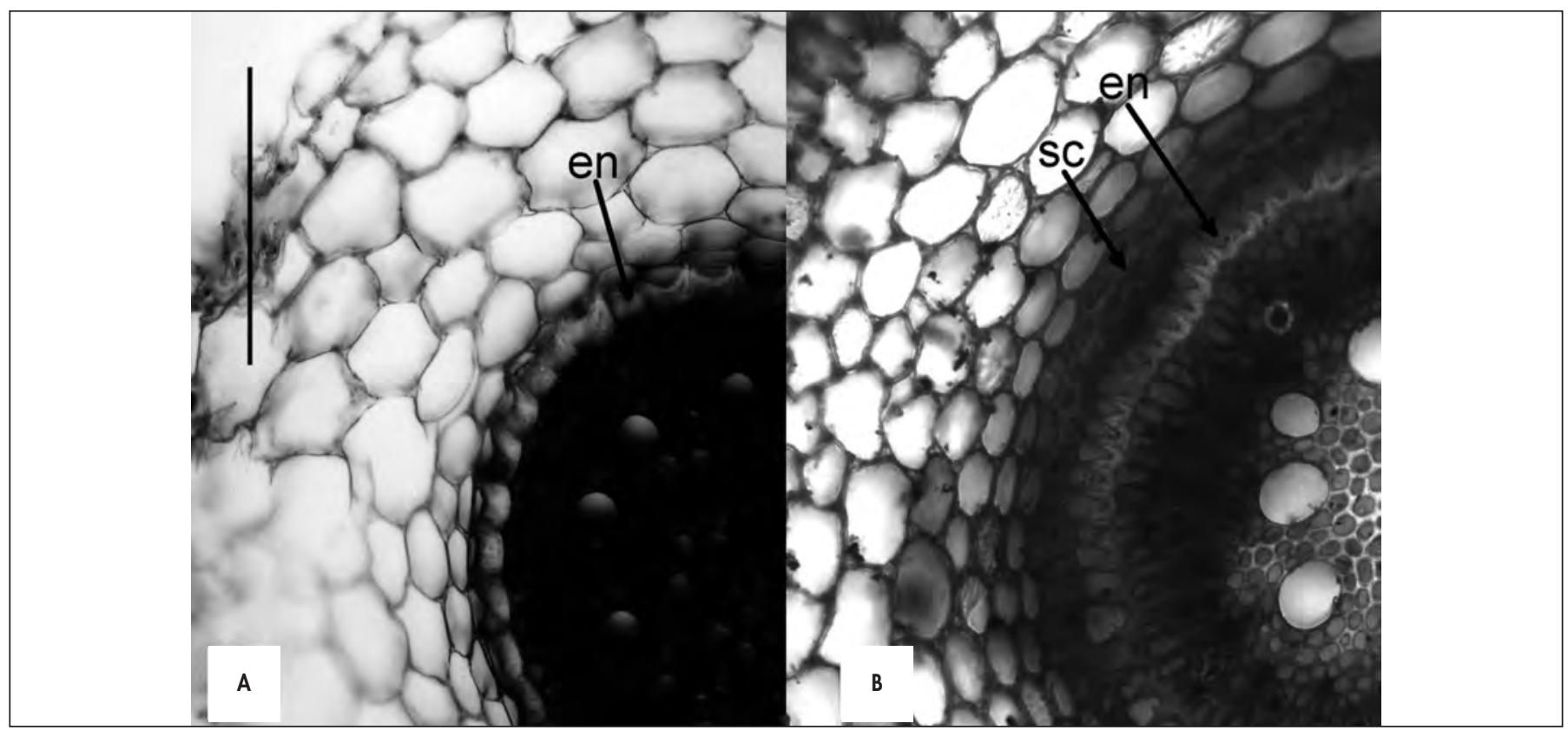

Fig. 1. - Root anatomy in cross-sections stained with safranin. A. Avenula hackelii (Henriq.) Holub (SEV [86752]); B. Pseudarrhenatherum pallens (Link) Holub (SEV [86754]). [en $=$ endodermis; $\mathrm{sc}=$ periendodermic sclerenchyma].

[Bar $=0.2 \mathrm{~mm}$ ] 
In Arrhenatherum album and Avenula hackelii (Fig. 1A) the endodermis is composed of approximately square cells, almost totally plugged by deposits of suberin, with a small lumen next to the outer wall. The sclerification of cortex cells was not observed. On the contrary in Pseudarrhenatherum pallens (Fig. 1B) the endodermis is formed by cells extended radially, with an inner ' $\mathrm{V}$ '-shaped suberin deposit leaving a lumen half as large as the cutting surface. A two to three row layer of sclerenchyma cells are observed around the endodermis. As asserted in Gervais (1973) the endodermis of Pseudarrhenatherum is different from those of Arrhenatherum, Avenula and Helictotrichon.

\section{Leaf blade anatomy (Fig. 2)}

Details of sclerenchyma girders and the arrangement of the chlorenchyma are shown in figure 2 for Avenula pratensis subsp. iberica (St.-Yves) O. Bolòs \& Vigo and A. pubescens. In Avenula pratensis subsp. iberica, the subepidermal strands of sclerenchyma are substantially thinner than the marginal ones, and some of them are connected to the vascular strand forming thin, 'I'-shaped girders. In A. pubescens the marginal strands are less developed and the subepidermal strands of sclerenchyma are very robust, even more than the marginal ones, forming rounded girders with main lateral vascular strands. The differentiation of a palisade chlorenchyma is observed in Avenula pratensis subsp. iberica, whereas in A. pubescens all chlorenchyma cells are nearly isodiametric. Other Avenula taxa have palisade chlorenchyma (LóPEZ \& DEVESA, 1991) and girders, when present, are 'I'-shaped (GERVAIS, 1973; ROMEROZARCO, 1984b; RÖSER, 1989).

\section{Morphology of lodicules (Fig. 3)}

The morphological characteristics of lodicules in Arrhenatherum elatius subsp. baeticum Romero Zarco, Pseudarrhenatherum pallens, Helictotrichon sarracenorum (Gand.) Holub, H. sedenense (DC.) Holub subsp. sedenense, Avenula bromoides subsp. pauneroi Romero Zarco and A. pubescens are summarized in figure 3. Avenula pubescens differs remarkably from the others by having shorter $(<1 \mathrm{~mm})$ and irregularly lobed lodicules (see also Romero-ZARCO, 1984b: Fig. 5; RÖSER, 1989: Fig. 8). The remaining species have longer lodicules ( $>1 \mathrm{~mm})$, with a lanceolate membranous portion, with or without a

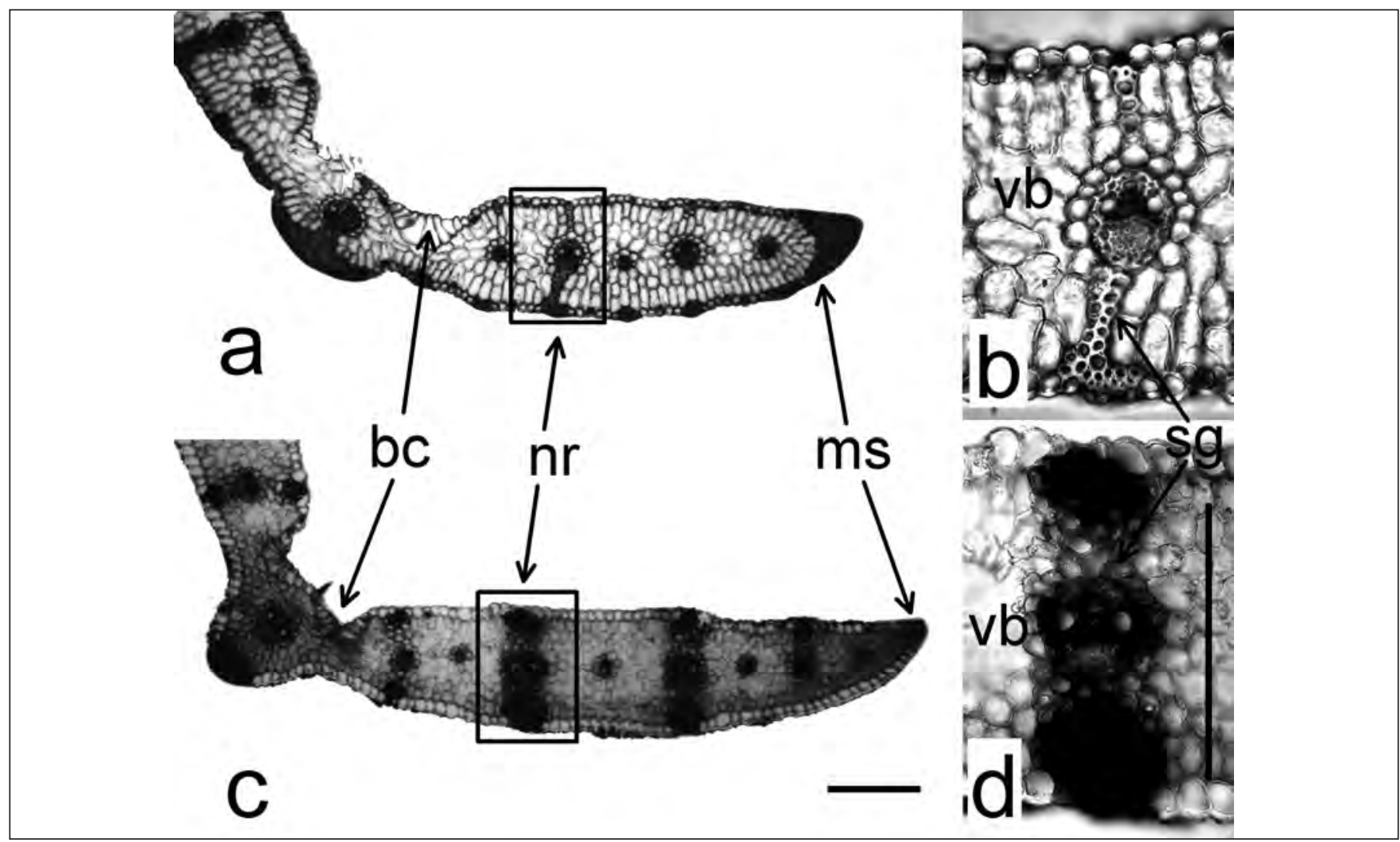

Fig. 2. - Leaf blade cross-sections from sterile innovations, stained with safranin. A-B. Avenula pratensis subsp. iberica (St.-Yves) O. Bolòs \& Vigo (SEV [77590]); C-D. Avenula pubescens (Hudson) Dumort. (SEV [86747]). [ $b c=$ bulliform cells, $\mathrm{ms}=$ marginal sclerenchyma, $\mathrm{nr}=$ nerve region, $\mathrm{sg}=$ sclerenchyma girders, vb $=$ vascular bundle].

[Bars $=0.2 \mathrm{~mm}$ ] 


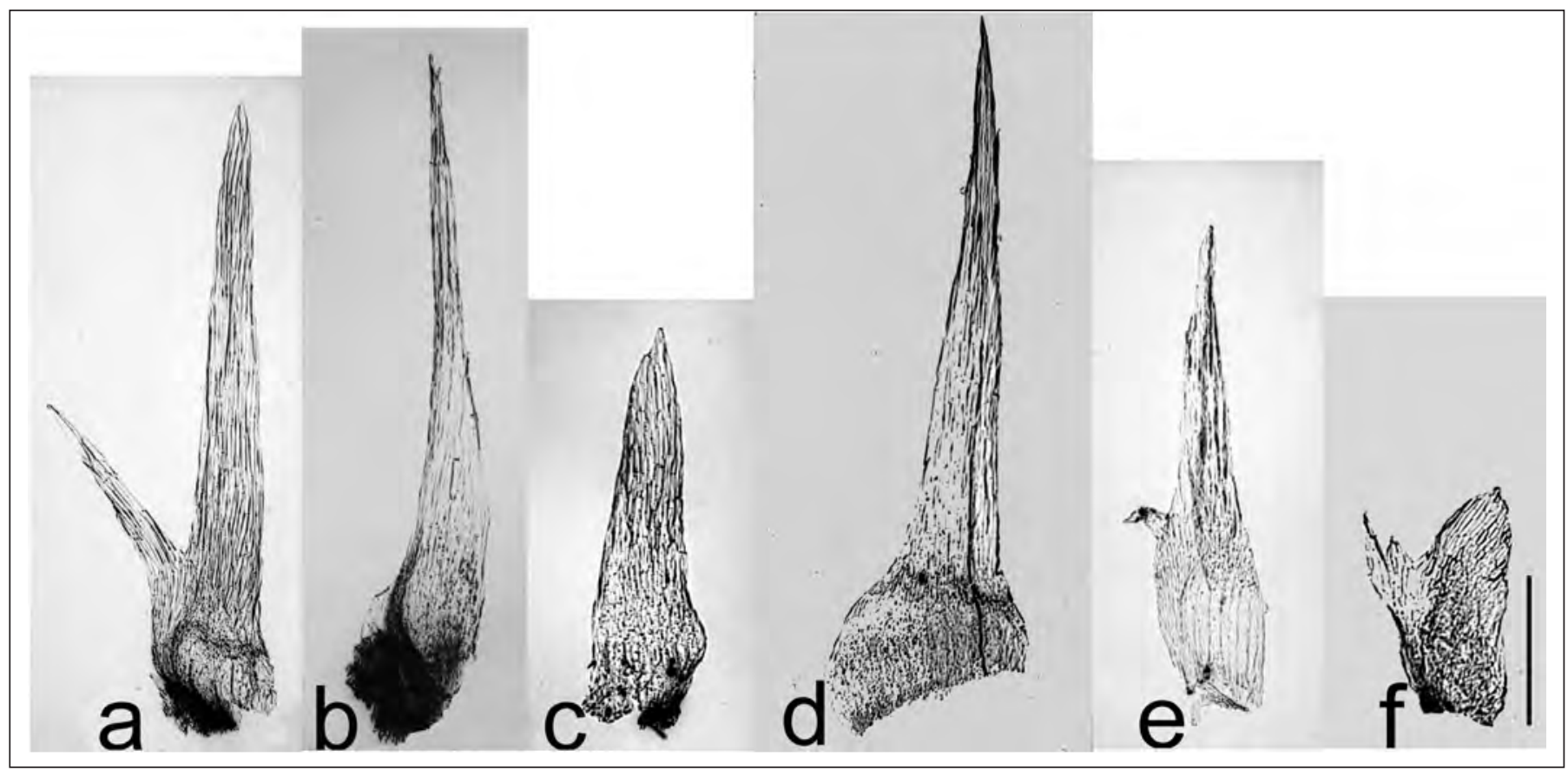

Fig. 3. - Morphology of the lodicules in perennial oat grasses. A. Arrhenatherum elatius subsp. baeticum Romero Zarco (SEV [78626]); B. Pseudarrhenatherum pallens (Link) Holub (SEV [86754]); C. Helictotrichon sarracenorum (Gand.) Holub (SEV [86651]) ; D. Helictotrichon sedenense (DC.) Holub subsp. sedenense (SEV [77616]); E. Avenula bromoides subsp. pauneroi Romero Zarco (SEV [77506]); F. Avenula pubescens (Hudson) Dumort. (SEV [86747]).

$[$ Bar $=0.5 \mathrm{~mm}]$

lateral lobe or tooth. In all Arrhenatherum taxa investigated, the presence of a lateral lobe or tooth is a variable character, even between the basal and apical floret within the same spikelet (ROMERO-ZARCO, 1985a). This character is less variable in species of Pseudarrhenatherum, Helictotrichon s.s. and Avenula. A lobe is always observed in most Eurasian Avenula species (A. pubescens excluded); the lobe is located at or below the middle on the lateral margin facing the palea, and its size is variable. Pseudarrhenatherum and most Eurasian Helictotrichon taxa investigated have entire lodicules, with the exception of $H$. sedenense subsp. sedenense, that has a small lateral tooth in some cases (ROMERO-ZARCO, 1984a; RÖSER, 1989). Lodicules in Avena s.s. (BAUM, 1977; ROMERO-ZARCO, 1996) are similar to Helictotrichon, containing a lanceolate membranous portion, and with or without a small (sometimes tiny) lateral tooth.

\section{Morphology of the embryos (Fig. 4)}

Some differences between species were observed in the morphology of epiblast. Several types of epiblasts have been described in Avena, some with rounded apical margins and others with more or less truncated margins (BAUM, 1977). Figure 4 shows the morphology of embryos extracted from mature caryopses of the following perennial oats: Arrhenatherum album var. erianthum (Boiss. \& Reut.) Romero Zarco,
A. elatius subsp. elatius, Pseudarrhenatherum longifolium, Helictotrichon sedenense subsp. sedenense, H. cantabricum (Lag.) Gervais, Avenula pubescens, A. pratensis subsp. iberica, A. gervaisii Holub subsp. gervaisii, A. bromoides (Gouan) H. Scholz subsp. bromoides and A. marginata (Lowe) Holub var. marginata. Aside from the differences in size (probably attributable to the size of the caryopsis itself), variations in two characters are observed: the form of the epiblast and the apex of the scutellum.

The combination of both characters allows us to define three types of embryos in perennial oat grasses:

1. "Arrhenatherum" type, characteristic of this genus, with rounded epiblast and scutellum.

2. "Helictotrichon" type, with truncated or somewhat emarginated epiblast, and subobtuse or rounded scutellum, present in Helictotrichon, Pseudarrhenatherum and Avenula pubescens.

3. "Avenula" type, with epiblast similar to the "Helictotrichon" type and scutellum with nipple-shaped apex, present in most Avenula species (A. pubescens excluded).

According to NegBi \& SARgent (1986: 252, Fig. 7), the scutellum of Avena fatua L. resembles the subobtuse one of Helictotrichon sedenense subsp. sedenense (Fig. 4D). 

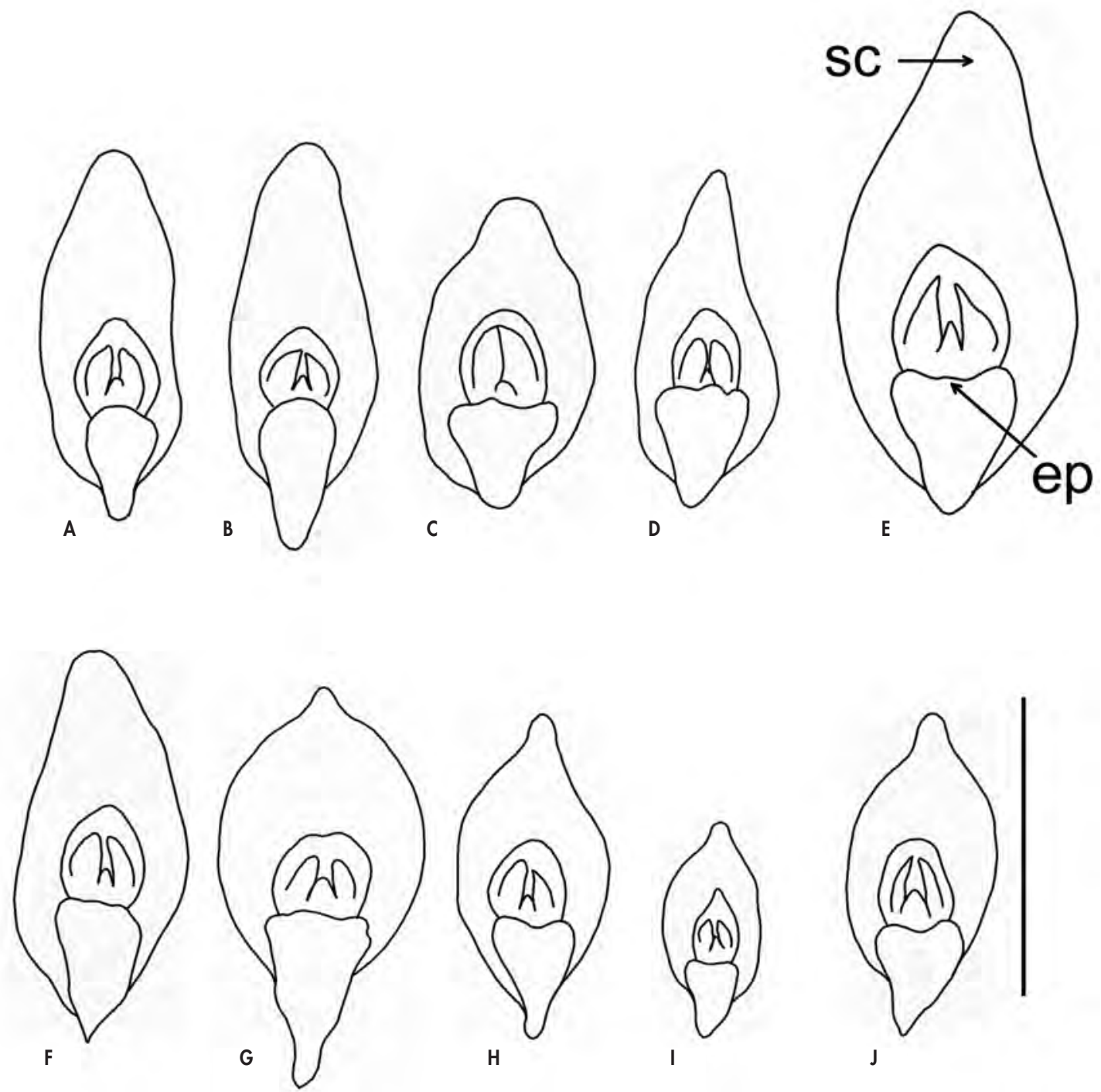

Fig. 4. - Morphology of the embryos in perennial oat-grasses (frontal view). A. Arrhenatherum album var. erianthum (Boiss.) Romero Zarco (SEV [78472]); B. A. elatius (L.) J. Presl \& C. Presl subsp. elatius (SEV [78612]); C. Pseudarrhenatherum longifolium (Thore) Holub (SEV [66721]); D. Helictotrichon sedenense (DC.) Holub subsp. sedenense (SEV [77613]); E. Helictotrichon cantabricum (Lag.) Gervais (SEV [77605]); F. Avenula pubescens (Hudson) Dumort. (SEV [86748]); G. Avenula pratensis subsp. iberica (St.-Yves) O. Bolòs \& Vigo (SEV [77573]); H. Avenula gervaisii Holub subsp. gervaisii (SEV [86683]); I. Avenula bromoides (Gouan) H. Scholz subsp. bromoides (SEV [77484]); J. Avenula marginata (Lowe) Holub var. marginata (SEV [79499]). [sc = scutelum; ep = epiblast].

[Drawn by author] [bar $=1 \mathrm{~mm}$ ]

\section{Taxonomic treatment}

\section{Avena S.S.}

Since the formal description of Avena by Linnaeus in 1753, many genera have been attributed to the tribe Aveneae. In the last 100 years the main subject of discussion in the taxonomy of Avena has focused on the separation of annual species (Avena s.s.) with respect to perennial ones [Helictotrichon s.1., that is: including Avenula (HoluB, 1958; RÖSER, 1989), Arrhenatherum (PotzTAL, 1951), and Pseu - darrhenatherum (RÖSER \& al., 2009)]. The main stumbling block has been the existence of Avena macrostachya Coss. \& Durieu, a perennial species, endemic to northwestern Africa, that has spikelets similar to other annuals in the genus. In the analysis of RÖSER \& al. (2001), A. macrostachya appears as an isolated lineage, occupying a basal position with respect to Helictotrichon s.s. and not clustered with A. sativa L. QuintANAR \& al. (2007) included eight annual Avena species, and A. macrostachya is placed between two Avena s.s. clades. 
These two clades are well defined based on morphological features of the spikelets:

1. the species near A. ventricosa Coss. (see Avena sect. Ventricosa Coss., ROMERo-ZARCO, 1996);

2. the remaining species (A. sativa, A. barbata Link, etc.).

Avena macrostachya is found in a similar position in another phylogenetic tree (RoDIONOv \& al., 2005), although sister to $A$. ventricosa group, and distantly related to $A$. sativa.

According to WINTERFELD \& al. (2009) karyotype features suggest that $A$. macrostachya is close to the $\mathrm{C}$-genome species of Avena (i.e. A. eriantha Durieu). These results support retaining A. macrostachya in Avena s.s., as proposed by BAUM (1968) who based his conclusion on morphological and anatomical characters (large glumes and sclerenchyma not present surrounding the endodermis in the root).

Avena L., Sp. Pl.: 79. 1753.

Lectotypus designated by BRITTON \& BROwn, 1913): Avena sativa L.

Diagnosis. - Annuals (with the exception of A. macrostachya); roots without sclerenchyma surrounding endodermis; culms with (2-)3-6 visible nodes; leaves convolute, relatively soft and flexible; cross-section with numerous secondary nerves, scarcely pronounced ribs, bulliform cells scarcely developed, forming several rows between the nerves, 'I'-shaped girders of colourless parenchyma, and subepidermal sclerenchyma in small, scarcely developed strands. Spikelets (12-)16-41(-48) mm long, (1-)2-4(-5) florets, completely developed, bisexual; equal or unequal glumes, almost as long as the whole spikelet, rounded on the back, glabrous, with (5-)7 or more nerves; lemma generally hairy towards the base, somewhat scabrous towards the apex; awn dorsal, generally with a strongly twisted column -exceptionally flattened or not developed in cultivated forms-; palea strongly 2-keeled, keels minutely ciliate; lodicules longer than ovary, lanceolate, entire or with a small lateral tooth. Caryopsis furrowed; hilum linear; embryo with a rounded or truncated epiblast and subobtuse scutellum.

Species and distribution. - 24-31 species, some of them cultivated derivatives; West Mediterranean and Macaronesia is the main centre of species diversity.

\section{Arrhenatherum vs Pseudarrhenatherum}

The delimitation of Arrhenatherum presents two problems. First its separation from Helictotrichon and second, the splitting of Pseudarrhenatherum as proposed by RouY (1913, 1921). There are three traditional morpho-anatomical criteria used to delimit these genera.

The first criterion used is the composition of spikelets. Arrhenatherum elatius and related species are clearly separable from other perennial oats by having two unequal florets that are joined at maturity; the lower floret masculine, with a strong subbasal awn; the upper floret bisexual, with a rudimentary, subapical awn, sometimes absent. It is evident that this configuration must be understood as a specialized polyandry syndrome in the context of the family. The majority of the remaining species of the group have spikelets with several similar, bisexual florets, all of them articulated with the rachilla, so that the dispersal unit (diaspora) is a single floret. Nevertheless some Avena and Helictotrichon species have spikelets with a reduced number of florets (frequently only two of them well developed) remaining united at maturity, since only the lower floret is articulated with the rachilla. The result is the configuration of a synaptospermic diaspora. In Avena this phenomenon occurs in some species belonging to different sections (A. sterilis L., A. murphyi Ladizinsky and A. eriantha; see for example Romero-ZARCO, 1996: Fig 1). Among the European Helictotrichon species, this specialized configuration of spikelets occurs in a small group of closely related, central European species, the group of $H$. parlatorei (J. Woods) Pilger (see RöSER, 1989: 65-76). In all these cases the two florets of the spikelets are similar, both provided with a well developed, dorsal awn. However, in the two unique species included in the genus Pseudarrhenatherum (Holub, 1980; RoMeroZARCO, 1985c), spikelets are formed by two different florets, both completely developed and bisexual, the lower floret with a well developed, dorsal awn, the upper floret without awn or with a reduced, straight subapical one.

Four kinds of major modifications in the structure of the spikelets occur in oats grasses:

1. reduction to two completely developed florets, rarely only one in some cultivars;

2. synaptospermy;

3. morphological differentiation between the lower floret and the upper one;

4. polyandry.

In synaptospermic Avena species, the spikelets have 2-4 (-5) florets (see RoMERo-ZARCO, 1996), but only cultivated forms have two morphologically different florets. In Arrhenatherum, the spikelets reach the maximum degree of modification, with reduction, differentiation, and polyandry. Obviously, synaptospermy cannot occur in Arrhenatherum, since the spikelets contain a unique fruit, but the atrophy of the joint at the base of the second flower does occur. In Pseudarrhenatherum the three first phenomena occur together, but not polyandry. In the species of Helictotrichon parlatorei group (RÖSER, 1989), together with certain endemic atypical species from Atlas Range (Avena Jahandiezii Litard. and A. breviaristata Barratte, included by Holub, 1962, 1976 in Avenula), synaptorpermy occurs, occasionally accompanied by the reduction of spikelets to two fertile florets, but there is no clear upward differentiation as in Pseudarrhenatherum. 
The second critieria used to separate species of Arrhenatherum from Pseudarrhenatherum is foliar anatomy. Arrhenatherum leaves are similar to those of Avena, i.e. relatively soft, with scarcely developed subepidermal sclerenchyma and less protruding ribs. The leaves of Pseudarrhenatherum are rigid, similar to those of Paleartic Helictotrichon species, with numerous, well-marked ribs above, with abundant subepidermal sclerenchyma forming ' $\mathrm{T}$ '-shaped girders and, in more xerophilic species, a continuous layer of subepidermal sclerenchyma beneath. The variability observed among Pseudarrhenatherum species is parallel to that occurring in Helictotrichon (see Romero-ZARCO, 1985c).

The third criterion is based on the anatomical characteristic of the root as described by GervaIS $(1968,1973)$. The endodermis is surrounded by a more or less heavy layer of sclerenchyma cells in the roots of the European Helictotrichon species, as well as in Pseudarrhenatherum. This character does not occur in Avena species (including A. macrostachya), Avenula, or Arrhenatherum s.s. In addition, the form of the endodermic cells are different in Helictotrichon when compared with Pseudarrhenatherum: in the former, the cells are \pm rounded, with a thick internal reinforcements of suberin and a reduced lumen, whereas in the later the cells are extended radially and have a broad lumen. This detail was observed by Gervais (1973) in P. longifolium and is verified here in P. pallens.

Two additional criteria are added here: the morphology of the embryos and the presence of macrohairs on the back of lemmas (excluding the callus). The embryos of Arrhenatherum differ by having rounded epiblasts, not truncated or emarginated epiblasts, like the other genera studied (Fig. 4). Macrohairs are present on lemmas of Pseudarrhenatherum, Arrenatherum and some Avena and Avenula s.l. species and not in Eurasian and American species of Helictotrichon (FINOT \& al., 2005; Romero-ZArco, 1984a, 1984b, 1985a, 1985c, 1996).

Four schemes regarding the classification are:

1. to maintain a broad criterion for Helictotrichon, including Arrhenatherum and Pseudarrhenatherum;

2. to separate Arrhenatherum and Helictotrichon maintaining Pseudarrhenatherum within the first;

3. the same but including Pseudarrhenatherum in Helictotrichon;

4. to completely separate these three genera.

How have molecular studies contributed to these questions? GREBENSTEIN \& al. $(1995,1998)$ have demonstrated with different molecular markers, that Arrhenatherum elatius clearly occupies a different position from Avena and from European Helictotrichon s.s. species. However, no Pseudarrhenatherum species where included in these studies. RöSER \& al. (2001) concluded that Pseudarrhenatherum should be included in Helic- totrichon s.s. on the basis of its 5S rDNA sequence, but only the most common species, P. longifolium, was studied, and no Arrhenatherum species were included in their analysis. A study of the whole group would have supported their conclusion in this respect. QUINTANAR \& al. (2007) in their phylogram on nuclear ITS data, separate clearly Arrhenatherum elatius from Helictotrichon s.s., but Pseudarrhenatherum longifolium is nested in Helictotrichon. Similar relationships are seen in recent studies (SCHNEIDER \& al., 2009; WINTERFELD \& al., 2009). One might assume that Pseudarrhenatherum longifolium should not be included in Arrhenatherum, but it could be included in Helictotrichon if the phylogenetic position of Pseudarrhenatherum pallens were clarified. Meanwhile, the most coherent position according to available data is to maintain the independence of these three genera until an analysis including all taxa with more molecular markers is completed.

Arrhenatherum P. Beauv., Ess. Agrostogr. 55: 1812.

Lectotypus (designated by PFeIfFer, 1872: 274): Avena elatior L. ( $\equiv$ Arrhenatherum elatius (L.) J. Presl \& C. Presl).

Taxonomic characters and diagnosis. - See ROMERoZARCO (1985a).

Species and distribution. - Only five species, primarily found in the Mediterranean Basin and SW Asia. The polymorphic A. elatius is the most frequent species, extending from Macaronesia to Siberia and introduced elsewhere.

Pseudarrhenatherum Rouy in Bull. Soc. Bot. France 68: 401. 1921.

$\equiv$ Thorea Rouy, Fl. France 14: 142. 1913 (non Thorea Bory in Ann. Mus. Hist. Nat. 12: 127. 1808 [nom. illeg.].

Typus: Avena longifolia Thore ( $\equiv$ Pseudarrhenatherum longifolium (Thore) Rouy).

Nomenclature. - See Rouy (1921) and Romero-ZArCo (1985c).

Taxonomic characters and diagnosis. - See RomeroZARCO (1985c).

Species and distribution. - Two species: the West-European, acidophilic $P$. longifolum, with the southernmost known populations in South Spain and Morocco, and P. pallens, endemic from a few localities near Lisbon, growing on calcareous substrates.

\section{Avenula vs Helictotrichon}

The question of recognizing Avenula as separate from Helictotrichon has been suitably discussed by several authors using morphological and anatomical characters (GERVAIS, 1973; Holub, 1962; RoMERO-ZARCO, 1984b). Most distinguishing characteristics of the former with respect to the later are based 
on leaf and root anatomy. The Eurosiberian and Mediterranean species of Helictotrichon s.s. have a layer of sclerenchyma surrounding the endodermis that is not present in Avenula s.l. (that is, including Tricholemma (Röser) Röser). Moreover, leaf blades are bilaterally symmetrical in Avenula s.l., since there are no ribs, and bulliform cells form rows along each side of the adaxial midrib. Other important characters such as palea hairiness, lodicule shape and the form of awn columns are heterogeneous in Avenula s.l., A. pubescens has glabrous paleas, short, ovate or obovate lodicules and terete or square awn column in crosssection; A. jahandiezii (here included in Tricholemma together with $A$. breviaristata) has similar lodicules and awn columns, but minutely ciliate paleas found in many grasses; the remaining Avenula species have ciliate paleas, long, lanceolate lodicules, and flattened awn column with pale margins.

Therefore, RöSER (1989) in his first treatment, maintained a broad concept of Helictotrichon by recognizing four subgenera:

1. Helictotrichon subgen. Helictotrichon, includes species with ribbed leaves and strongly twisted awn columns, terete or square in cross-section, from Europe, N Africa, Western Asia and one North American species.

2. Helictotrichon subgen. Pubavenastrum (Vierh.) Holub, monospecific, includes only $H$. pubescens (Hudson) Pilger, a species with a wide distribution but isolated morphologically and phylogenetically, with conduplicate leaf blades as in Avenula species, awn like in Helictotrichon s.s., short Trisetum type lodicules (BAUM, 1968), and palea with smooth keels, a unique configuration in the group.

3. Helictotrichon subgen. Tricholemma Röser includes two rare species from NW Africa, characterized by lemmas with the central nerve prominent and hairy at the base; awn like in Helictotrichon s.s., and leaf blades very similar to those of Avenula.

4. Helictotrichon subgen. Pratavenastrum (Vierh.) Holub includes species with conduplicate leaf blades and \pm flattened awn columns; distributed mainly in the Mediterranean basin.

All molecular analyses published to date agree in separating Helictotrichon s.s. from most Avenula species (that is, excluding Tricholemma). The results of QuinTANAR \& al. (2007) are compatible with the hypothesis that the four subgenera defined by RÖSER (1989) constitute separate phylogenetic clades. According to morphological and anatomical characters and molecular analyses, I think the simplest taxonomic solution is to recognize four genera. Coming to the same conclusion RÖSER \& al. (2009) established the generic category for the four groups: Helictotrichon subgen. Tricholemma is upgraded to generic rank as Tricholemma and Homalotrichon is accepted for Helictotrichon subgen. Pubavenastrum as an independent genus.
So, in the author's opinion, the species at present classified under Avenula must be separated into the following three genera Tricholemma, Avenula and the new Helictochloa Romero Zarco. A nomenclature summary, diagnoses and diversity are proposed for the following four genera formerly included in Helictotrichon s.l. (sensu RÖSER, 1989):

1. Tricholemma, its generic rank has been well defended by Röser \& al. (2009);

2. Avenula, a monotypic genus including $A$. pubescens. The separation of $A$. pubescens in a monotypic genus (apart from the rest of species at present classified under Avenula) is according to morphological and anatomical characters analyzed above;

3. Helictochloa Romero Zarco, a large and new genus including the remaining Avenula species (Avenula subgen. Avenula sensu Romero-ZArCo, 1984b);

4. Helictotrichon s.s.

Tricholemma (Röser) Röser in Schlechtendalia 19: 34. 2009.

$\equiv$ Helictotrichon subgen. Tricholemma Röser in Diss. Bot. 145: 46. 1989.

Typus: Avena jahandiezii Litard. (= Tricholemma jahandiezii (Litard.) Röser)

Diagnosis. - Perennials, densely caespitose; roots without sclerenchyma surrounding endodermis; culms with 1-2 visible nodes, sometimes subbulbous at the base. Leaf blades flat, conduplicate or junciform, not furrowed above, with or without thin ribs beneath, very hard or relatively soft, but rigid, with several or numerous secondary nerves; abaxial midrib and margins outstanding, without long hairs; bulliform cells forming a row each side of the adaxial midrib; without girders and subepidermal sclerenchyma (T. jahandiezii) or with subepidermal sclerenchyma forming 'I'-shaped girders at the lateral nerves (T. breviaristatum (Barratte) Röser). Spikelets 13-18 mm long, with 2-3 developed bisexual florets, two upper floret not or scarcely exceeding the upper glume, apical floret reduced; glumes slightly unequal, keeled in the back, glabrous, 3-nerved; rachilla disarticulating only above the glumes; lemmas with a row of hairs on the back, along the lower part of the central nerve, the rest glabrous; awn without pale margins, dorsally inserted and with a strongly twisted column, or reduced and subapically inserted, with or without a slightly twisted column; palea strongly 2-keeled, keels minutely ciliate; lodicules as long or shorter than the ovary, ovate or obovate, with a \pm truncate, usually dentate apex. Caryopsis furrowed; hilum linear; embryo not seen.

Species and distribution. - Two endemic species in NW Africa: T. jahandiezii from Morocco (Middle Atlas) and T. breviaristatum, endemic from E Algeria.

Nomenclature and taxonomy. - See RöSER \& al. (2009). 
Avenula (Dumort.) Dumort. in Bull. Soc. Bot. Belg. 7: 68 . 1868.

$\equiv$ Trisetum sect. Avenula Dumort., Observ. Gramin. Belg.: 122. 1823.

$\equiv$ Avena sect. Avenastrum W. D. J. Koch, Syn. Fl. Germ. Helv.: 795.1837 [nom. illeg.].

$\equiv$ Homalotrichon Banfi, Galasso \& Bracchi in F. Conti, G. Abbate, Aless. \& C. Blasi, Annot. Cheklist Italian Vasc. Fl.: 18. 2005 [nom. illeg.].

Lectotypus (designated by CHASE, 1939): Avena pubescens Hudson (三Avenula pubescens (Hudson) Dumort.).

Perennial, loosely caespitose; roots without sclerenchyma surrounding endodermis; culms with 1-3 visible nodes. Leaf blades flat or \pm conduplicate, not furrowed, relatively soft but rigid, with long hairs; bulliform cells forming a row each side of the adaxial midrib; with abaxial midrib and margins scarcely evident; secondary nerves few; well developed subepidermal sclerenchyma forming ' $\mathrm{O}$ '-shaped girders at lateral nerves. Spikelets 14-20 mm long, with 3-4 developed bisexual florets, two upper floret not or scarcely exceeding the upper glume, apical floret reduced; glumes unequal, keeled on the back, somewhat scabrid on the central nerve at the base, the lower glume 1-3-nerved, the upper glume 3-nerved; rachilla disarticulating above the glumes and between the florets; lemmas glabrous (except for the callus); awned dorsally, with a strongly twisted, rounded column, without pale margins; palea scarcely 2-keeled, with glabrous keels; lodicules as long or shorter than the ovary, ovate or obovate, 2-3-lobed or with a irregularly dentate apex. Caryopsis furrowed; hilum linear; embryo with a truncated epiblast and obtuse scutellum.

Nomenclature. - See ROMERO-ZARCO (1984b), RÖSER (1989: 44) and Holub (1976: 288).

Lectotypification. - There are two different lectotopyfications of the generic name Avenula: a) Avena pubescens Hudson, designated by CHASE (1939: 568) and ignored by most European taxonomists (HoLUB, 1977; ROMERO-ZARCO, 1984b; RÖSER, 1989; RÖSER \& al., 2009) and b) A. pratensis L., designated by BREISTROFFER (1966). Only these two species were cited by DUMORTIER (1824) in the original description of Trisetum sect. Avenula, the basyonim of Avenula, and both fit the protologue. According to McNeILL \& al. (2006, art. 10.5), the first lectotypification is accepted, and the correct name for the monotypic genus including A. pubescens is Avenula. The name Homalotrichon is then illegitimate (MCNEILL \& al., 2006, art. 52.1).

Species and distribution. - Only the diploid Avenula pubescens, extends from Spain to China: from submediterranean Europe through Central Europe to continental regions of Middle Asia and Central Siberia (cf. RöSER, 1997: 109).
Helictochloa Romero Zarco, gen. nov.

Typus: Avena bromoides Gouan ( moides (Gouan) Romero Zarco).

$=$ Avena sect. Pratenses Rouy, Fl. France 14: 132. 1913. Typus: A. pratensis L.

$=$ Avena subsect. Ecostatae St.-Yves in Candollea 4: 374. 1931. Lectotypus (designated here): A. pratensis $\mathrm{L}$.

= Avenastrum ser. Pratenses Roshev. in Kom. \& al., Fl. CCCP 2: 273. 1934. Typus: Avena pratensis L. ( $\equiv$ Avenastrum pratense (L.) Opiz).

$=$ Avenastrum sect. Pratavenastrum Vierh. in Verh. Ges. Deutsch. Naturf. 85: 672. 1914. $\equiv$ Helictotrichon subgen. Pratavenastrum (Vierh.) Holub in Nemec. \& al., Philipp Maxmillian Opiz Bedeut. Pflanzentaxon.: 125. 1958. Typus: Avena pratensis L. (三 Avenastrum pratense (L.) Opiz).

$=$ Avenochloa Holub in Acta Horti Bot. Prag. 1962: 82. 1962 [nom. illeg]. Typus: Avena planiculmis Schrad. ( $\equiv$ A. planiculmis (Schrad.) Holub).

$=$ Helictotrichon sect. Scleravenastrum Holub in Nemec. \& al., Philipp Maxmillian Opiz Bedeut. Pflanzentaxon.: 126. 1958. $\equiv$ Avenula sect. Scleravenastrum (Holub) Holub in Folia Geobot. Phytotax. 11: 294. 1976. Typus: Avena hackelii Henriq. ( $\equiv$ Helictotrichon hackelii (Henriq.) Henrard).

- Avenula mult. auct.

Ab Helictotricho sensu stricto praecipue differt foliis conduplicatis, nervo medio dorsaliter notato, margine incrassato. Ab Avenulae sensu stricto praecipue differt foliis glabris vel scabridis; carinis paleae ciliolatis; lodiculis lanceolatis. A Tricholemmate praecipue differt lemmate nervo mediano non prominente instructo. A generibus praecedentibus atque differt columella aristae sectione transversa applanata. Gramina ob folia in sicco saepe helica Helictochloa nominata.

Perennials, loosely or densely caespitose; roots without sclerenchyma surrounding endodermis; culms with 1-3 visible nodes. Leaf blades flat, conduplicate or \pm junciform, not furrowed above, sometimes with thin ribs beneath, relatively hard and rigid; bulliform cells forming a row each side of the adaxial midrib; margins and abaxial midrib prominent, cartilaginous; secondary nerves numerous or not; with or without 'I'-shaped girders of sclerenchyma and/or colourless parenchyma; subepidermal sclerenchyma in \pm developed small islands, rarely forming a continuous layer beneath. Spikelets 10-36 mm long, with (2-)3-9(-12) developed, bisexual florets, two or more upper florets exceeding the glumes, apical floret reduced; glumes unequal, keeled on the back, somewhat scabrous on the nerves, the lower glume with (1-)3-5 nerves, the upper glume with 3-5(-7) nerves; rachilla disarticulating 
above the glumes and between the florets; lemmas glabrous or sericeous towards the base, awned dorsally; awn with a loosely twisted column, \pm flattened in cross-section, with pale margins; palea strongly 2-keeled, keels minutely ciliate; lodicules longer than the ovary, lanceolate, with a lateral, \pm developed lobe. Caryopsis furrowed; hilum linear; embryo with a truncate or somewhat emarginate epiblast, scutellum with a nipple-shaped apex.

Etymology. - From Greek helictos, by the spirally twisted leaves when dry, and chloe, green grass.

Nomenclature and taxonomy. - See HoluB (1976) for Avenochloa Holub. According to McNeILl \& al. (2006, art. 22.6) Avena pratensis is the type species of infrageneric names derived or similar to its epithet.

According to the taxonomic criteria here defended, a number of 40 taxa (25 species) accepted by DOGAN (1985), RöSER (1989, 1996), SAUER (1984), SAuer \& ChMELITSCHEK (1976), ROMERO-ZARCo (1984b), ROSHEVITS \& SHISHKIN (1934) or WU $\&$ Phillips (2006) must be transferred to the new genus (see Appendix 1).

SAINT-Yves (1931) included in his Avena subsect. Ecostatae 8 species belonging to 3 different genera:

1. Avena jahandiezii (classified here within Tricholemma) is discarded as a possible lectotypus because he considered it an intermediate species (SAINT-YveS, 1931: 425);

2. Avena pubescens (type species of Avenula), discarded as lectotype by the same reason;

3. A. hackelii Henriq. (genus Helictochloa); this species was considered by SAINT-Yves (1931: 435) an atypical species in the group or even a possible hybrid between two species belonging to different subsections;

4. Avena pratensis (genus Helictochloa), the most complex and extended species of this group in Europe;

5. A. versicolor Vill. (genus Helictochloa);

6. A. blaui Asch. \& Janka ["Blavii"] (genus Helictochloa);

7. A. bromoides (genus Helictochloa), another species complex, extended around the Mediterranean basin;

8. A. breviaristata (classified here within Tricholemma) considered by SAINT-YVES (1931: 489) of doubtful classification due to some affinities with his subsect. Anomalae.

So, only species 4 to 7 can be properly selected as lectotype. Avena pratensis have been designated here because it was previously selected by VIERHAPPER (1906), ROUY (1913), and RosheviTs \& SHISHKIN (1934) as the type species for other infrageneric taxa including this species group.
Species and distribution. - Several polyploid species complexes and some \pm isolated endemic species previously classified as Avenula or Helictotrichon. The number of species ranges from 20 to 30 according to different taxonomic treatments. Two main centres of diversity: West Mediterranean and Balkan-Aegean region. A secondary centre is in the European Alpes. Some species extending north and east in Europe to Asia. Only one species in N America.

Helictotrichon Besser in Schultes \& Schultes fil., Mant. 3: "326" [526]. 1827.

Lectotypus (designated by SCHWEICKERDT, 1937: 185): Avena sempervirens Vill. ( $\equiv$ Helictotrichon sempervirens (Vill.) Pilger).

Perennials, densely or loosely caespitose, sometimes mat forming; roots with sclerenchyma surrounding endodermis; culms with 1-3 visible nodes. Leaf blades convolute, \pm flattened, involute, junciform or setaceous, furrowed above, with protruding ribs, very hard or relatively soft, but rigid, with several or numerous lateral nerves; abaxial midrib and margins not outstanding; bulliform cells forming several rows between the nerves, sometimes reduced or not developed between the distal nerves; sclerenchyma forming ' $\mathrm{T}$ 'shaped girders across the main nerves and 'I'-shaped or incomplete girders at the secondary nerves; subepidermical sclerenchyma frequently forming a continuous layer beneath. Spikelets 7.5-20 mm long, with 2-4 developed bisexual florets, apical floret reduced; glumes unequal, keeled in the back, somewhat scabrous on the keel near the apex, the lower glume 1-3-nerved, the upper glume 3-5-nerved, almost as long as the spikelet; rachilla disarticulating only above the glumes or between the florets too; lemmas 7-18 mm long, generally 2-dentate, glabrous (except for the callus) or somewhat scabrous towards the apex; awns \pm equally developed, without pale margins, dorsally inserted and with a strongly twisted column, terete or square in cross-section; palea strongly 2-keeled, keels minutely ciliate; lodicules longer than the ovary, lanceolate, generally entire, rarely with a small lateral tooth. Caryopsis furrowed; hilum linear; embryo with truncate epiblast and obtuse or subobtuse scutellum.

Nomenclature. - See RöSER (1989: 44) (under Helictotrichon subgen. Helictotrichon).

Species and distribution. - Approximately 42 species following different regional taxonomic treatments, some of then recently described (COPE, 2006; ROMERO-ZARCO, 2007). A wellknow Mediterranean-Balkanic group of approximately 12 species, some of them forming polyploid complexes (ROMERO-ZARCO, 1984a, 1985b; RöSER, 1989). At least 20 species in Tropical and South Africa, with two different diversity centres: E Africa and 
Cape Region. Perhaps only nine species in Asia, but some of them polymorphic, as $H$. junghuhnii (Buse) Henrard. Only one species in N America: H. mortonianum (Hitchc.) Parodi, and the South American H. bulbosum (Hitchc.) Parodi.

\section{Key for Avena related genera present in the Mediterranean region}

1. Leaf blades not furrowed above; bulliform cells forming a row each side of the adaxial midrib 2

1a. Leaf blades furrowed above; bulliform cells forming several rows between the nerves, sometimes reduced or not developed between the distal nerves 4

2. Awns with a loosely twisted column, \pm flattened in crosssection, with pale margins. Spikelets with (2-)3-9(-12) florets, two or more upper florets exceeding the glumes. Lodicules lanceolate, generally with a subbasal lateral lobe. Mainly Mediterranean, sub-Mediterranean or alpine species Helictochloa

2a. Awns with a strongly twisted column, rounded or quadrangular in cross-section (rarely very reduced), rarely with pale margins. Spikelets with (2-)3-4 florets, two upper floret not or scarcely exceeding the upper glume. Lodicules ovate or obovate, 2 or 3-lobed or with a dentate apex. Eurosiberian or Atlasic species 3

3. Leaf blades with long hairs. Lemmas glabrous (except for the callus). Eurosiberian species Avenula

3a. Leaf blades without long hairs. Lemmas with a row of hairs on the back, along the lower part of the central nerve. Endemic species from Algeria and Morocco

Tricholemma

4. Annuals, very rarely perennial. Lower glumes with (5-)7 or more nerves. Lemmas (10-)12-33(-36) mm long. Mediterranean or Eurosiberian species ................ Avena

4a. Perennials. Lower glumes 1-3-nerved. Lemmas 5-17 (-18) $\mathrm{mm}$ long 5

5. Lemmas glabrous (except for the callus) or somewhat scabrous towards the apex. Spikelets 7.5-20 mm long, with 2-4 florets; rachilla disarticulating only above the glumes or between the florets too. Awns \pm equally developed, dorsally inserted

Helictotrichon

5a. Lemmas hairy. Spikelets 5-12(-14) mm long, with two developed florets. Rachilla disarticulating only above the glumes. Awn of the lower floret inserted near the base or near the middle, awn of the upper floret reduced, subapically inserted
6. Awn of the lower floret inserted near the middle of the lemma. Leaf blades with very protruding ribs, relatively hard and rigid. Culms without corms. Subatlantic species Pseudarrhenatherum

6a. Awn of the lower floret inserted near the base of the lemma. Culms frequently with the basal internodes swollen into globose corms. Leaf blades relatively soft and flexible. Mediterranean, Iranoturanian and Eurosiberian species

Arrhenatherum

\section{General discussion}

According to the taxonomic scheme adopted here, the conduplicate structure of the leaf blade, with two rows of bulliform cells flanking the central nerve, a character usually used to the separate Avenula s.l. from Helitotrichon, does not have a unique origin in the group. This is not surprising for researchers of leaf anatomy. In figure 2 the anatomical characters of the leaf blade in Avenula pubescens and in A. pratensis subsp. iberica (now classified in the new genus Helictochloa) have been compared. In species here included within Helictochloa, the strands of subepidermal sclerenchyma are much thinner than marginal strands, and in many species (H. pratensis (L.) Romero Zarco, H. marginata (Lowe) Romero Zarco, and related species) these strands are united to the vascular bundles forming relatively thin, 'I'-shaped girders. In Avenula pubescens the marginal strands are less developed and the subepidermal strands are very robust, forming ' $\mathrm{O}$ '-shaped girders. Beside this, differentiation of a palisade chlorenchyma is found in Helictochloa pratensis but not in Avenula pubescens. LóPEz \& Devesa (1991) also found palisade chlorenchyma in Helictochloa bromoides subsp. bromoides (sub. Avenula). The remaining species of Helictochloa all have palisade chlorenchyma according to many figures previously published (ROMERO-ZARCO, 1984b; RöSER, 1998). The anatomical structure of the leaf blade in Avenula pubescens may be the result of analogous changes also having originated in the typical leaves of Helictochloa and Tricholemma.

In the genus Tricholemma, the two known species present very different leaf blade structures. In T. jahandiezii, the leaves have only sclerenchyma in front of the central nerve (beneath) and in the margins, a unique pattern of sclerenchyma distribution in oat grasses (see RöSER, 1989: 31, Fig. 4). However, in $T$. breviaristatum the distribution of sclerenchyma in crosssection (see SAINT-YvES, 1931: Fig. 37) is similar to that of certain xeromorphic populations of Helictochloa pruinosa (Hackel \& Trabut) Romero Zarco from Middle Atlas, originally described by SAINT-YVES (1931: 485, Fig. 36) as Avena bromoides subvar. dolosa St.-Yves. This remarkable difference between two closely related species, can be seen in the different development of the sclerenchymatous tissue probably in response to habitat. In the case of T. jahandiezii, the absence 
of subepidermal strands in front of lateral nerves can be explained by an extreme reduction of the sclerenchyma, perhaps as an adaptation to the relatively humid habitat where it grows: "garriga" schrublands at the Middle Atlas up to $1600 \mathrm{~m}$ above see level in deep calcareous soils, with autumnal precipitations of $1000 \mathrm{~mm}$ or more and frequent fog (RöSER, 1996: 214). On the contrary, Tricholemma breviaristatum is an endemic xeromorphic species of the Djebel Sahari, in NW Algeria, zone of median height mountains with Mediterranean type vegetation, containing elements of the Quercetea ilicis A. Bolòs \& O. Bolòs 1950 (RöSER, 1996: 214). A similar relationship between humidity and development of sclerenchyma in the leaves has been described between mesomorphic and xeromorphic Helictochloa species (RÖSER, 1989, 1996, 1997, sub Helictotrichon subg. Pratavenastrum) and in Pseudarrhenatherum species (ROMERO-ZARCO, 1985c).

The remarkable development of the marginal strands of sclerenchyma is a shared characteristic between Tricholemma and Helictochloa. A detailed phylogenetic analysis will be necessary to find out if this foliar structure has arisen independently in both genera or is the result of common descent. The molecular analyses available do not clarify the question. Nuclear ITS sequences studies (GRENBENSTEIN \& al., 1998; QUINTANAR \& al., 2007) align T. jahandiezii closer to Helictotrichon s.s. than to Avenula or Helictochloa. Nevertheless RÖSER \& al. (2001) in his analysis of 5S rDNA sequences proposed an isolated and basal situation of this species in respect to the group. Both results are not absolutely contradictory and they could be resolved if $T$. breviaristatum were studied. Unfortunately, T. breviaristatum has not been collected since May 1882 (RÖSER \& al., 2009). In conclusion, the so called "Avenastrum type" leaf structure (POTZTAL, 1951), may be the result of convergent processes resulting in anatomical simplification.

The splitting of species showing a unique combination of morphological characters within monotypic genera or genera with 2-3 taxa, is frequently encountered in the Aveneae tribe (Avenella, Danthoniastrum, Lagurus L., Mibora Adans., Ventenata, among others). Some cases, like the new Tricholemma genera, are possibly, relics of a substratum of diversity from which other genera, at present in the diversification process arose, and may be a significant example of the otherwise poor supraspecific endemism in the orophytic Mediterranean flora of N Africa RöSER (1996: 245). The distribution of Tricholemma species corresponds to the southern edge of the Mediterranean vegetation in N Africa, where orophytic taxa were isolated at the end of the Tertiary. This, together with the great differences (possibly quantitative) in leaf anatomy and spikelet morphology (T. breviaristatum has very reduced awns) suggests an ancient derivation and a long history for this genus, which would support its basal position with respect to the group as shown in the dendrogram of RöSER \& al. (2001).
The next challenge in the taxonomy of the group would be to investigate the phylogenetic relationship between Paleartic, Paleotropical and South African species of Helictotrichon. The species from south and east Africa, together with some from SE Asia, differ from Paleartic species in several characters; specifically in the morphology of the lemma, but also by a greater variability in the morphology of lodicules, awns and leaves. New data are needed for a clear delimitation of Helictotrichon outside of Europe.

\section{Acknowledgements}

This work was financially supported by the Spanish "Plan Andaluz de Investigación" of the Junta de Andalucía (RNM 204) and Dirección General de Investigación Científica y Técnica through projects "Flora iberica" VII(2) (CGL2006-00817) and "Flora iberica" VIII(2) (CGL2009-08178). I thank Dr Anass Terrab for the French abstract. An anonymous reviewer kindly improved the first manuscript.

\section{References}

BAum, B. R. (1968). Delimitation of the genus Avena (Gramineae). Canad. J. Bot. 46: 121-132.

BAUM, B. R. (1977). Oats: wild and cultivated. Biosystematics Research Institute, Canada Department of Agriculture, Ottawa.

Breistroffer, M. (1966). Flore abrégée du Diois (Drôme). Bull. Soc. Bot. France 110, Sess. Extr.: 42-143.

Britton, N. L. \& A. Brown (1913). Ill. Fl. N.U.S. ed. 2. New York.

Chase, A. (1939). Avena. In: Britton, N. L. \& L. M. Underwood (ed.), N. Amer. Fl. 17: 568-570. New York Botanical Garden.

Conti, F., G. Abbate, A. Alessandrini \& C. Blasi (2005). An annotated checklist of the Italian vascular flora. Ministerio dell'Ambiente, Roma.

CoPE, T. A. (2006). Three new Arabian grasses. Kew Bull. 61 : 243-244.

Dogan, M. (1985). Helictotrichon. In: Davis, P. H. (ed.), Fl. Turkey 9: 308-313. Edinburgh University Press.

DUMORTIER, B. C. (1824). Observations sur les graminées de la flore belgique. Tournay.

Duval-Jouve, J. (1863). Note sur les caractères que les arètes et les feuilles peuvent fournier pour la division en sections du genre Avena. Bull. Soc. Bot. France 10: 50-55.

Finot, V. L., P. M. Peterson, F. O. Zuloaga, R. J. Soreng \& O. MAtThei (2005). A revisión of Trisetum (Poaceae: Pooideae: Aveninae) in South America. Ann. Missouri Bot. Gard. 92: 533568.

GERVAIS, C. (1968). Sur un critère anatomique nouveau utilisable dans la taxinomie chez les avoines vivaces. Ber. Schweiz. Bot. Ges. 78: 369-372.

GERVAIS, C. (1973). Contribution à l'étude cytologique et taxinomique des avoines vivaces. Denkschr. Schweiz. Naturf. Ges. 88. 
Grebenstein, B., O. Grebenstein, W. Sauer \& V. Hemleben (1995). Characterization of a highly repeated DNA component of perennial oats (Helictotrichon, Poaceae) with sequence similarity to a A-genome-specific satellite DNA of rice (Oryza). Theor. Appl. Genet. 90: 1101-1105.

Grebenstein, B., M. Röser, W. Sauer \& V. Hemleben (1998). Molecular phylogenetic relationships in Aveneae (Poaceae) species and other grasses as inferred from ITS1 and ITS2 rDNA sequences. Pl. Syst. Evol. 213: 233-250.

Holub, J. (1958). Bemerkungen zur Taxonomie der Gattung Helictotrichon Bess. In: Nemec, B. \& al. (ed.), Philip Maximilian Opiz und seine Bedeutung für die Pflanzentaxonomie: 101-133. Verlag der Tschekoslowakischen Akademien der Wissenschaften.

HoluB, J. (1962). Ein Beitrage zur Abgrenzung der Gattungen in der Tribus Aveneae: die Gattung Avenochloa Holub. Acta Horti Bot. Prag. 1962: 75-86.

HoluB, J. (1976). A newly adopted restriction of illegitimity in generic names and its consequence for Avenochloa Holub 1962. Folia Geobot. Phytotax. 11: 281-300.

Holub, J. (1977). Notes on some species of Avenula and Helictotrichon. Preslia 49: 203-221.

Holub, J. (1980). Pseudarrhenatherum. In: Tutin, T. G. \& al. (ed.), Fl. Eur. 5: 217. Cambridge.

Kerguélen, M. (1975). Les Gramineae (Poaceae) de la flore française. Essai de mise au point taxonomique et nomenclaturale. Lejeunia 75.

López, J. \& J. A. Devesa (1991). Contribución al conocimiento de la anatomía foliar de las Aveneae (Poaceae, Pooideae) del Centro-Oeste de España. Anales Jard. Bot. Madrid 48: 171-187.

McNeILl, J. \& al. (ed.) (2006). International Code of Botanical Nomenclature (Vienna Code). Regnum Veg. 146.

NegBi, M. \& J. A. SARgent (1986). The scutellum of Avena: a structure to maximize exploitation of endosperm reserves. Bot. J. Linn. Soc. 93: 247-258.

Pfeiffer, L. K. G. (1872). Nomenclator Botanicus. Vol 1. Kassel.

PotzTal, E. (1951). Anatomisch-systematische Untersuchungen an der Gattungen Arrhenatherum und Helictotrichon. Bot. Jahrb. Syst. 75: 321-332.

Quintanar, A., S. Castroviejo \& P. Catalán (2007). Phylogeny of the tribe Aveneae (Pooideae, Poaceae) inferred from plastid trnTF and nuclear ITS sequences. Amer. J. Bot. 94: 1554-1569.

Rodionov, A. V., N. B. Tyupa, E. S. Kim, E. M. Machs \& I. G. LOSKUTOV (2005). Genomic configuration of the autotetraploid oat species Avena macrostachya inferred from comparative analysis of ITS1 and ITS2 sequences: on the oat karyotype evolution during the early events of the Avena species divergence. Russian J. Genet. $41:$ 518-528.

Romero-ZArCo, C. (1984a). Revisión del género Helictotrichon Besser ex Schultes \& Schultes fil. (Gramineae) en la Península Ibérica. I. Estudio taxonómico. Anales Jard. Bot. Madrid 41: 98-124.

Romero-Zarco, C. (1984b). Revisión taxonómica del género Avenula (Dumort.) Dumort. en la Península Ibérica e Islas Baleares. Lagascalia $13: 39-146$.
Romero-Zarco, C. (1985a). Revisión del género Arrhenatherum Beauv. (Gramineae) en la península Ibérica. Acta Bot. Malac. 10: 123-154.

ROMERO-ZARCO, C. (1985b). Revisión del género Helictotrichon Besser ex Schultes \& Schultes fil. (Gramineae) en la Península Ibérica. II. Estudio experimental. Anales Jard. Bot. Madrid 42: 133-154.

Romero-Zarco, C. (1985c). Estudio taxonómico del género Pseudarrhenatherum Rouy (Gramineae) en la Península Ibérica. Lagascalia $13: 255-273$.

Romero-Zarco, C. (1993). Observaciones sobre las Avenula del grupo marginata en Andalucía. Acta Bot. Malac. 18: 147-151.

Romero-Zarco, C. (1996). Sinópsis del género Avena L. (Poaceae, Aveneae) en España peninsular y Baleares. Lagascalia 18: 171198.

Romero-Zarco, C. (2007). Helictotrichon devesae, a new endemic grass species from Castilla-La Mancha (Central Spain). Anales Jard. Bot. Madrid 64: 205-211.

RÖSER, M. (1989). Karyologische, systematische und chorologische Untersuchungen an der Gattung Helictotrichon Besser ex Schultes \& Schultes im westlichen Mittelmeergebiet. Diss. Bot. 145.

RÖSER, M. (1996). Ecogeography of the grass genus Helictotrichon (Poaceae: Aveneae) in the Mediterranean and adjacent regions. Pl. Syst. Evol. 203: 181-281.

RöSER, M. (1997). Patterns of diversification in Mediterranean oat grasses (Poaceae: Aveneae). Lagascalia 19: 101-120.

RÖSER, M. (1998). Character evolution of the genus Helictotrichon (Poaceae: Aveneae) reconsidered in view of recent results in Ibero-Mauritanian and Eurasian species. Flora 193: 425-447.

RöSER, M., E. Döring, G. Winterfeld \& J. Schneider (2009). Generic realignments in the grass tribe Aveneae (Poaceae). Schlechtendalia 19: 27-38.

Röser, M., G. Winterfeld, B. Grebenstein \& V. HEMLEBEnt (2001). Molecular diversity and physical mapping of 5S rDNA in wild and cultivated oat grasses (Poaceae: Aveneae). Molec. Phylogen. Evol. 21: 198-217.

Roshevits, R. Y. \& B. K. SHishkin (1934). Avenastrum Jessen. In: Komarov, V. L. \& al. (ed.), Fl. CCCP 2: 270-281.

RouY, G. (1913). Fl. France 14. Paris.

RouY, G. (1921). Le Thorea longifolia devient le Pseudarrhenatherum longifolium Rouy. Bull. Soc. Bot. France 68: 401-402.

SAint-Yves, A. (1931). Contribution à l'étude des Avena sect. Avenastrum (Eurasie et région méditerranéenne). Candollea 4: 353-504.

Sauer, W. (1984). Die Gattung Avenula (Dumort.) Dumort. auf der Balkanhalbinsel. Acta Bot. Croat. 43: 315-328.

Sauer, W. \& H. Chmelitschek (1976). Beiträge zur Kennits ausdauernder Wildhafer: Die Gattung Avenula (Dumort.) Dumort. in den Ostalpen. Mitt. Bot. Staatssamml. München 12: 513-608.

Schneider, J., E. Döring, K. W. Hilu \& M. Röser (2009). Phylogenetic structure of the grass subfamily Pooideae based on comparison of plastid matK gene-3'trnK exon and nuclear ITS sequences. Taxon 58: 405-424. 
Schweickerdt, H. (1937). A revision of the South African species of Helictotrichon Bess. ex Schultes. Bothalia 3: 185-203.

Soreng, R. J., J. I. DAVIS \& M. A. VoIOnMAA (2007). A phylogenetic analysis of Poaceae tribe Poeae sensu lato based on morphological characters and sequence data from three plastic-encoded genes: evidence for reticulation, and a new classification for the tribe. Kew Bull. 62: 425-454.

Vierhapper, F. (1906). Zur systematik der Gattung Avena. Verh. Zool.-Bot. Ges. Wien 56: 369-370.

Winterfeld, G., E. Döring \& M. Röser (2009). Chromosome evolution in wild oat grasses (Aveneae) revealed by molecular phylogeny. Genome 52: 361-380.

WinTERFELD, G. \& M. RÖSER (2007). Disposal of ribosomal DNAs in the chromosomes of perennial oats (Poaceae: Aveneae). Bot. J. Linn. Soc. 155: 193-210.

Wu, Z. \& S. M. Phillips (2006). Helictotrichon. In: Wu, C.-Y. \& P. H. RAven (ed.), Fl. China 22: 317-322. Science Press. 
Appendix 1. - New combinations for Helictochloa Romero Zarco

Helictochloa adsurgens (Simonk.) Romero Zarco, comb. nova

$\equiv$ Avena adsurgens Simonk., Enum. Fl. Transsilv.: 574. 1887.

Helictochloa adsurgens subsp. ausserdorferi (Asch. \& Graebn.)

Romero Zarco, comb. nova

$\equiv$ Avena alpina subsp. ausserdorferi Asch. \& Graebn., Syn. Mitteleur. Fl. 2(1): 261. 1899.

Helictochloa aetolica (Rech. fil.) Romero Zarco, comb. nova

$\equiv$ Avenastrum aetolicum Rech. fil. in Beih. Bot. Centralbl., Abt. 2, 54: 680. 1936.

Helictochloa agropyroides (Boiss.) Romero Zarco, comb. nova

$\equiv$ Avena agropyroides Boiss., Diagn. Pl. Orient. 13: 50. 1854.

Helictochloa albinervis (Boiss.) Romero Zarco, comb. nova $\equiv$ Avena albinervis Boiss., Voy. Bot. Espagne 2: 656 . 1844.

Helictochloa albinervis var. gaditana (Romero Zarco) Romero Zarco, comb. et stat. nov.

$\equiv$ Avenula sulcata subsp. gaditana Romero Zarco in Lagascalia 13: 124. 1984.

Helictochloa armeniaca (Schischk.) Romero Zarco, comb.

nova

$\equiv$ Avena armeniaca Schischk. in Izv. Tomsk. Gosud. Univ. 81: 418. 1929.

Helictochloa blaui (Asch. \& Janka) Romero Zarco, comb. nova

$\equiv$ Avena blaui Asch. \& Janka in Természetrajzi Füz. 1: 99. 1877.

Helictochloa blaui subsp. aenigmatica (D. Lange) Romero Zarco, comb. nova

$\equiv$ Helictotrichon blaui subsp. aenigmaticum D. Lange in Biblioth. Bot. 144: 181. 1995.

Helictochloa bromoides (Gouan) Romero Zarco, comb. nova $\equiv$ Avena bromoides Gouan, Hort. Monsp.: 52. 1762.

Helictochloa bromoides subsp. pauneroi (Romero Zarco)

Romero Zarco, comb. nova

$\equiv$ Avenula bromoides subsp. pauneroi Romero Zarco in Lagascalia 13: 114. 1984.

Helictochloa cincinnata (Parl.) Romero Zarco, comb. nova $\equiv$ Bromus cincinnatus Ten., Fl. Med. Univ. 1: 52. 1823.

Helictochloa cintrana (Röser) Romero Zarco, comb. nova $\equiv$ Helictotrichon cintranum Röser in Taxon 41:60. 1992.

Helictochloa compressa (Heuff.) Romero Zarco, comb. nova $\equiv$ Avena compressa Heuff. in Flora 18: 244. 1835.

Helictochloa crassifolia (Font Quer) Romero Zarco, comb. nova

$\equiv$ Avena crassifolia Font Quer in Butl. Inst. Catalana Hist. Nat. 20: 189. 1920.
Helictochloa dahurica (Kom.) Romero Zarco, comb. nova $\equiv$ Avena planiculmis subsp. dahurica Kom., Fl. Kamtschatka 1: 159. 1927.

$\equiv$ Avenastrum dahuricum (Kom.) Roshev. in Kom. \& al., Fl. CCCP 2: 275. 1934.

Helictochloa gervaisii (Holub) Romero Zarco, comb. nova $\equiv$ Avenula gervaisii Holub in Preslia 49: 205. 1977.

Helictochloa gervaisii subsp. arundana (Romero Zarco) Romero Zarco, comb. nova

$\equiv$ Avenula gervaisii subsp. arundana Romero Zarco in Lagascalia 13: 108. 1984.

Helictochloa hackelii (Henriq.) Romero Zarco, comb. nova $\equiv$ Avena hackelii Henriq. in Bol. Soc. Brot. 20: 87. 1905.

Helictochloa hackelii var. algarbiensis (Romero Zarco) Romero Zarco, comb. nova

$\equiv$ Avenula hackelii var. algarbiensis Romero Zarco in Lagascalia 13: 136. 1984.

Helictochloa hookeri (Scribn.) Romero Zarco, comb. nova $\equiv$ Avena hookeri Scribn. in Hackel, True Grasses: 123. 1890.

Helictochloa hookeri subsp. schelliana (Hackel) Romero Zarco, comb. nova

$\equiv$ Avena schelliana Hackel in Trudy Imp. S.-Peterburgsk. Bot. Sada 12: 419. 1892.

$\equiv$ Helictotrichon hookeri subsp. schellianum (Hackel) Tzvelev in Novosti Sist. Vyssh. Rast. 8: 68. 1971.

Helictochloa levis (Hackel) Romero Zarco, comb. nova

$\equiv$ Avena levis Hackel in Oesterr. Bot. Z. 27: 122. 1877.

Helictochloa lusitanica (Romero Zarco) Romero Zarco, comb. nova

$\equiv$ Avenula pratensis subsp. lusitanica Romero Zarco in Lagascalia 13: 95. 1984.

$\equiv$ Helictotrichon lusitanicum (Romero Zarco) Röser in Flora 193: 438. 1998.

Helictochloa marginata (Lowe) Romero Zarco, comb. nova

$\equiv$ Avena marginata Lowe in Trans. Cambridge Philos. Soc. 6: 529. 1838.

Helictochloa marginata var. font-queriana (St.-Yves) Romero Zarco, comb. nova

$\equiv$ Avena pratensis var. font-queriana St.-Yves in Candollea 4: 465. 1931.

Helictochloa murcica (Holub) Romero Zarco, comb. nova $\equiv$ Avenula murcica Holub in Preslia 49: 206. 1977.

Helictochloa planiculmis (Schrad.) Romero Zarco, comb. nova $\equiv$ Avena planiculmis Schrad., Fl. Germ. 1: 381. 1806.

Helictochloa planiculmis subsp. angustior (Holub) Romero Zarco, comb. nova

$\equiv$ Avenula planiculmis subsp. angustior Holub in Preslia 49: 209. 1977. 
Helictochloa praeusta (Rchb.) Romero Zarco, comb. nova $\equiv$ Avena praeusta Rchb., Fl. Germ. Excurs.: 140(5). 1831.

Helictochloa pratensis (L.) Romero Zarco, comb. nova $\equiv$ Avena pratensis L., Sp. Pl.: 80. 1753.

Helictochloa pratensis subsp. amethystea (Br.-B1.) Romero Zarco, comb. nova

$\equiv$ Avena pratensis subsp. amethystea Br.-Bl. in Commun. Stat. Int. Géobot. Médit. Montpellier 87: 223. 1945.

Helictochloa pratensis subsp. gonzaloi (Sennen) Romero Zarco, comb. nova

$\equiv$ Avena gonzaloi Sennen, Pl. Espagne 1925: nº 5454. 1925-1926 [in sched., cum notula].

$\equiv$ Avenula pratensis subsp. gonzaloi (Sennen) Romero Zarco in Lagascalia 13: 86. 1984.

Helictochloa pratensis subsp. iberica (St.-Yves) Romero Zarco, comb. nova

$\equiv$ Avena pratensis subsp. iberica St.-Yves in Candollea 4: 435. 1931.

Helictochloa pratensis subsp. hirtifolia (Podp.) Romero Zarco, comb. nova

$\equiv$ Avenastrum pratense subsp. hirtifolium Podp. in Cas. Morav. Zemsk. Mus. Brne 12: 272. 1912.
Helictochloa pruinosa (Hackel \& Trabut) Romero Zarco, comb. nova

$\equiv$ Avena pruinosa Hackel \& Trabut in Bull. Soc. Bot. France 36: 411. 1889.

Helictochloa xtalaverae (Romero Zarco) Romero Zarco, comb. nova

$\equiv$ Avenula $\times$ talaverae Romero Zarco in Lagascalia 13: 138. 1984.

Helictochloa versicolor (Vill.) Romero Zarco, comb. nova 三 Avena versicolor Vill., Prosp. Hist. Pl. Dauphiné: 17. 1779.

Helictochloa versicolor subsp. caucasica (Holub) Romero Zarco, comb. nova

$\equiv$ Helictotrichon versicolor prol. caucasicum Holub in Preslia 31: 51. 1959.

$\equiv$ Avenula versicolor subsp. caucasica (Holub) H. Scholz \& Valdés in Willdenowia 36: 663. 2006.

Helictochloa versicolor subsp. praetutiana (Arcang.) Romero Zarco, comb. nova

$\equiv$ Avena scheuchzeri subsp. praetutiana Arcang., Comp. Fl. Ital.: 777. 1882. 